\title{
O Direito Fundamental ao Ambiente como Direito a Prestações em Sentido Amplo 9
}

\author{
Anizio Pires Gavião Filho
}

\section{RESUMO}

O propósito desta investigação é encontrar justificação racional para uma teoria jurídica do direito fundamental ao ambiente como um direito a prestações em sentido amplo. Para isso, deve ser justificada a vinculação jurídica produzida pela noma do direito fundamental ao ambiente, contida na disposição do art. $225 \mathrm{da}$ Constituição brasileira de 1988, com o caráter de regra ou de princípio. Será decisivo demonstrar que o direito fundamental ao ambiente pode ser compreendido como um todo, integrado por um feixe de posições fundamentais jurídicas, pertencente à categoria do direito a algo, estrutura que permite a sua configuração como direito fundamental a prestações em sentido amplo: direito à proteção, direito à organização e ao procedimento e direito a prestaçóes em sentido estrito.

\footnotetext{
-A banca foi composta pela Professora Doutora Véra Maria Jacob de Fradera, Professora da Universidade Federal do Rio Grande do Sul e Doutora em Diteito pelá Universidade de Paris II - França, pelo Professor Doutor Roger Raupp Rios, Professor da Universidade Ritter dos Reis e Doutor en Direito pela Universidade Federal do Rio Grande do Sul, e pelo Professor Doutor José Rubens Morato Leite, Professor da Universidade Federal de Santa Catarina e Doutor em Direito pela Universidade Federal de Santa Catarina. A referida defesa foi presidida pelo Professor Doutor Luis Afonso Heck, Professor Adjunto da Universidade Federal do Rio Grande do Sul e Doutor em Dixeito pela Universidade Federal de Minas Gerais, orientador do referido trabalho.
} 